\title{
Effect of di-tertiary-butyl peroxide additive on combustion, performance and emissions of a karanja methyl ester fueled diesel engine
}

\section{Bhabani Prasanna Pattanaik}

KMBB College of Engineering and Technology

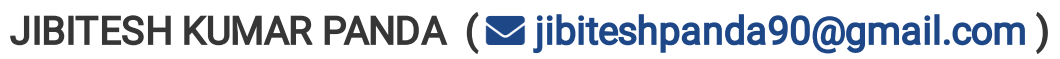

Anurag University https://orcid.org/0000-0002-9306-3769

\section{Santhosh Kumar Gugulothu}

NIT Andhara Pradesh

\section{Pradeep Kumar Jena}

GITA Bhubaneswar

\section{Original Article}

Keywords: Di-tertiary-butyl Peroxide, Karanja Methyl Ester, Biodiesel, Diesel Engine, NOx Emissions

Posted Date: February 15th, 2021

DOl: https://doi.org/10.21203/rs.3.rs-182648/v1

License: (a) (7) This work is licensed under a Creative Commons Attribution 4.0 International License. Read Full License 


\section{Abstract}

The present work studies the influence of di-tertiary-butyl peroxide (DTBP) as a cetane-improving additive to karanja methyl ester (KME) on the combustion, performance and emission characteristics of a diesel engine. KME produced by base catalyzed transesterification of non-edible karanja oil was blended with DTBP in different volume proportions to result KMED1 (99\% KME + 1\% DTBP), KMED2 (98\% KME + 2\% DTBP), KMED3 (97\% KME + $3 \%$ DTBP) and KMED5 (95\% KME + 5\% DTBP) fuel blends. With increase in DTBP content, viscosity was reduced, whereas the cold flow properties, cetane index and calorific value were enhanced. Engine test results exhibited improvement in brake thermal efficiency and brake specific energy consumption for all blends compared to neat KME. Combustion analysis showed improved combustion with rise in DTBP content in the blends. The CO, HC and $\mathrm{NO}_{\mathrm{x}}$ emissions with KME-DTBP blends were less compared to neat KME and the same significantly reduced with rise in DTBP percentage in the blends. This shows improved combustion due to more oxygen availability and improvement in fuel properties with addition of DTBP to KME. However, the $\mathrm{NO}_{\mathrm{x}}$ emissions were marginally higher with KME-DTBP blends compared to neat KME and diesel that may be further studied.

\section{Introduction}

In the last few decades, increase in global population, growth in industries and automobiles as well as change in human life style have led to increased demand and consumption of energy. Subsequently, fossil-based fuels, being the primary source of energy, are being consumed at a much faster rate for harness of energy. This leads to the risk of rapid depletion of these conventional fuels as well as environmental deterioration. Again, increased use of fossil fuels are responsible for harmful emissions to the atmosphere in the form of greenhouse gases (GHGs) and other pollutants. In recent years, the consequences of environmental degradation in the form of global warming, acid rain, climate change etc. have emerged as possible threat to the survival of humankind. Thus, it is the need of the hour to minimize the dependency on the fossil fuels through development of potential alternate energy sources. In this regard, researchers around the world are putting tremendous effort on development of alternate fuels for internal combustion engines. In recent times, biofuels have emerged as potential substitute fuel for engines. Compression ignition $(\mathrm{Cl})$ engines, usually known as diesel engines, are widely used owing to their suitability for medium and large commercial transport purpose. Many published literature have demonstrated the use of straight vegetable oils (SVOs), vegetable oil methyl ester or biodiesel, bioethanol etc. as potential fuel in $\mathrm{Cl}$ engines (Misra and Murthy 2011; Agarwal 2007; Demirbas 2007). Ramdhas et al. (2004) presented an expatiate review on the production and utilization of SVOs as fuel in $\mathrm{Cl}$ engines and verified that SVOs as fuel are less polluting compared to diesel. Mohanty et al. (2011) tested the use of polanga oil-diesel blends in different volume proportions in a $\mathrm{Cl}$ engine and reported decline in exhaust emissions with the blends compared to neat diesel operation. Demirbas (2003) examined various chemical and fuel properties of seventeen different SVOs and reported that the SVOs are too high in viscosity and density compared to diesel, whereas their biodiesels are more promising in terms of fuel properties and more convenient as $\mathrm{Cl}$ engine fuel. Nabi et al. (2009) reported lower CO, $\mathrm{HC}$ and $\mathrm{PM}$ emissions with cottonseed oil biodiesel in a diesel engine with slightly increased $\mathrm{NO}_{\mathrm{x}}$ emissions matched to those with diesel. Tan et al. (2012) studied the use of jatropha biodiesel blends in a diesel engine and reported that the $\mathrm{CO}, \mathrm{HC}$ and smoke emissions reduce with upsurge in biodiesel content in the blends and are minimum with neat biodiesel. However, they reported marginally higher $\mathrm{NO}_{\mathrm{x}}$ emissions with the biodiesel blends. Conversely, many researchers also claimed that biodiesels, owing to their poor cold flow characteristics, high viscosity, higher $\mathrm{NO}_{\mathrm{x}}$ emissions, higher oxygen content, and engine compatibility issues, are not appropriate for 
long-term usages in diesel engines (Pattanaik and Misra 2017; Yasin et al. 2014; Smith et al. 2010). In order to overcome these issues, efforts were made to improve biodiesel properties. This led to the research on the use of additive-doped biodiesel in $\mathrm{Cl}$ engines.

Many investigators examined the use of various additives with biodiesel with the intention of improving its fuel properties and combustion characteristics. Nayak and Pattanaik (2014) investigated the use of di-methyl carbonate as an additive with mahua biodiesel and reported significant drop in $\mathrm{CO}, \mathrm{HC}, \mathrm{NO}_{\mathrm{x}}$ and smoke emissions matched to neat biodiesel and diesel. Musthafa (2017) reported lower $\mathrm{CO}, \mathrm{HC}$ and $\mathrm{NO}_{\mathrm{x}}$ emissions for an uncoated diesel engine running on palm oil biodiesel with $1 \%$ di-tertiary-butyl peroxide (DTBP) additive. Roy et al. (2014) used different biodiesel blends with Wintro XC 30 additive in a $\mathrm{Cl}$ engine and reported improved fuel properties, lower $\mathrm{CO}, \mathrm{HC}$ and $\mathrm{NO}_{\mathrm{x}}$ emissions with higher BTE compared to diesel fuel. Similarly, many other works on the use of additive blended biodiesel fuel in $\mathrm{Cl}$ engines have reported better engine performance along with lower exhaust emissions (Lawan et al. 2020; Channappagoudra et al. 2018; Yang et al. 2016). In the current work, efforts were made to use karanja methyl ester (KME) blended with different volume proportions of a cetane enhancing additive (DTBP) in a $\mathrm{Cl}$ engine for study of various exhaust emission parameters. A comparative analysis of the obtained results were made with diesel fuel to investigate the improvement / deterioration in the engine performance and exhaust emissions. The objective of the current work is to completely replace mineral diesel oil in a $\mathrm{Cl}$ engine with biodiesel fuel produced from non-edible source. Further, the purpose of using DTBP as an additive to biodiesel is to improve its fuel properties, achieve better combustion and engine performance along with lowering the exhaust emissions.

\section{Materials And Methodology}

The methodology involved in the present work includes selection of a suitable SVO, development of biodiesel using base catalyzed transesterification, selection of a suitable cetane improving additive, preparation of biodiesel-additive blends in suitable volume proportions, fuel characterization of all the selected test fuels, application of the blended fuels in the selected test engine, carrying out the engine performance and emission tests using the selected fuels, recording the observed data and a comparative analysis of the obtained data. The detailed methodologies are elaborated in the following subsections.

\subsection{Preparation of Biodiesel and Fuel Blends}

In this work, Karanja (Pongamia Pinnata), a non-edible SVO source, was selected for production of Karanja biodiesel or KME. Neat Karanja oil (KO) was procured from M/s Sajjan Agarwal \& Co., Karanjia, Baripada, Odisha, India. Neat KO was initially filtered and a selected amount of the same was taken for preparation of biodiesel. A 5 L capacity biodiesel reactor (Make: M/s Gobind Machinery Works, India) was used for preparation of KME from neat KO. The selected quantity of neat KO was fed into the biodiesel reactor followed by preparation of a measured quantity of reagent mixture (Methanol $+\mathrm{KOH}$ ). The neat $\mathrm{KO}$ was initially heated to $40^{\circ} \mathrm{C}$ followed by mixing of the measured quantity of reagent mixture with it. After proper mixing of the same, transesterification was started and continued at $60^{\circ} \mathrm{C}$ for a period of $1.5 \mathrm{~h}$. After the reaction is over, the products were allowed to settle down overnight. Two distinct layers were visible with the upper layer being KME and the bottom layer being glycerol. Glycerol was collected into a container through the flush bottom valve. This was followed by collection of KME into another container following the same process. The raw KME obtained was then water washed for three times to obtain pure KME. Again, it was dried using a suitable procedure for removal of moisture. DTBP was 
procured from M/s Manik Chemicals, Kolkata, West Bengal, India. It is available in $100 \mathrm{ml}$ bottle container. DTBP is an organic compound that consists of a peroxide group bounded by two tertiary-butyl groups. It is one of the best stable organic peroxides. It is used as an excellent cetane improver. When the temperature of DTBP is increased beyond $100^{\circ} \mathrm{C}$, the peroxide bond undergoes homolysis. Due to this, it is used as a radical initiator in organic synthesis (Musthafa 2017). It has a chemical formula of $\mathrm{C}_{8} \mathrm{H}_{18} \mathrm{O}_{2} .1 \%, 2 \%, 3 \%$ and $5 \% \mathrm{v} / \mathrm{v}$ of DTBP was suitably mixed with neat KME to result four numbers of KME + DTBP fuel blends named as KMED1 (1\% DTBP + 99\% KME), KMED2 (2\% DTBP + 98\% KME), KMED3 (3\% DTBP + 97\% KME) and KMED5 (5\% DTBP + 95\% KME). Fuel characterization of all the prepared fuel blends along with KME and diesel was conducted as per standardized ASTM methods to study various fuel properties. The fuel characterization results are presented in Table 1.

Table 1

Fuel characterization results

\begin{tabular}{|llllllll|}
\hline Fuel Property & Diesel & KME & KMED1 & KMED2 & KMED3 & KMED5 & $\begin{array}{l}\text { ASTM } \\
\text { Standard }\end{array}$ \\
\hline Density at $20^{\circ} \mathrm{C}, \mathrm{kg} / \mathrm{m}^{3}$ & 835 & 846 & 843 & 842 & 840 & 839 & D4052 \\
\hline $\begin{array}{l}\text { Kinematic viscosity at } 40^{\circ} \mathrm{C}, \\
\text { CSt }\end{array}$ & 2.67 & 4.94 & 4.72 & 4.55 & 4.41 & 4.22 & D445 \\
\hline $\begin{array}{l}\text { Flash point, }{ }^{\circ} \mathrm{C} \\
\text { Calorific value, } \mathrm{MJ} / \mathrm{kg}\end{array}$ & 71 & 178 & 168 & 159 & 155 & 152 & D93 \\
\hline Cloud point, ${ }^{\circ} \mathrm{C}$ & 44.58 & 41.32 & 41.57 & 41.85 & 42.28 & 42.85 & D240 \\
\hline Pour point, ${ }^{\circ} \mathrm{C}$ & 6.6 & 11.5 & 10.9 & 10.5 & 10.2 & 10.1 & D2500 \\
\hline Cetane index & 3.2 & 5.8 & 5.3 & 4.7 & 4.4 & 4.6 & D97 \\
\hline Ash content, $\%$ & 49 & 51.2 & 53.8 & 54.8 & 55.6 & 56.8 & D4737 \\
\hline
\end{tabular}

\subsection{Experimental Engine Setup and Procedure}

The prepared fuel blends along with KME and diesel were tested in a computerized single-cylinder four-stroke water-cooled direct injection diesel engine attached to an eddy current dynamometer. The rated power of the engine was $5.2 \mathrm{~kW}$ at $1500 \mathrm{rpm}$. Necessary instrumentation were incorporated with the test engine for measurement of various engine parameters. The eddy current dynamometer is used for applying load on the engine. Two different fuel tanks were used for supply of diesel and biodiesel fuels to the engine. The engine exhaust line was connected to a five-gas analyzer (AVL Digas 444) and a smoke meter (AVL 437) for measurement of the exhaust emissions. The engine tests for each of the selected fuels was carried out at $0 \%$, $25 \%, 50 \%, 75 \%, 85 \%, 90 \%, 95 \%$ and $100 \%$ of the rated load. During all the engine experiments, diesel was used as the baseline fuel for necessary comparison of obtained data and the acquired data was stored in the attached computer. The main performance parameters studied were brake thermal efficiency (BTE), brake specific energy consumption (BSEC) and exhaust gas temperature (EGT). On the other hand, the important emission characteristics studied were $\mathrm{CO}, \mathrm{HC}$ and $\mathrm{NO}_{\mathrm{x}}$ emissions and smoke opacity. A schematic presentation of the experimental engine setup with all attached instrumentation can be seen in Fig. 1. The technical specifications of the test engine are presented in Table 2. 
Table 2

Technical specifications of the test engine

\begin{tabular}{|ll|}
\hline Particulars & Specification \\
\hline Make \& model & Kirloskar AV-1 \\
\hline Engine type & Computerized single-cylinder 4-stroke DI diesel engine \\
\hline Max. power & $5.2 \mathrm{~kW}$ \\
\hline Max. speed & $1500 \mathrm{rpm}$ \\
\hline Compression ratio & 17.5 \\
\hline Bore $\times$ Stroke & $110 \mathrm{~mm} \times 87.5 \mathrm{~mm}$ \\
\hline Swept volume & $661 \mathrm{cc}$ \\
\hline Injection pressure & 220 bar \\
\hline Injection nozzle opening & $23^{\circ} \mathrm{bTDC}$ \\
\hline Lubricating oil & SAE 20 W40 \\
\hline Cooling method & Water cooling \\
\hline Dynamometer & Eddy-current type \\
\hline
\end{tabular}

Figure 1. Schematic diagram of the experimental engine setup

\section{Uncertainty Analysis}

Various errors are subject to arise during an experimentation process. To identify those errors, uncertainty analysis of different parameters is carried out. At first, the engine performance parameters were checked for their respective accuracies which were based on the accuracies of the components (manufacturer declared accuracy) using them. After estimating the total

uncertainty ' $\mathrm{U}$ ' of a given quantity ' $\mathrm{Q}$ ', where $\mathrm{Q}=\mathrm{f}\left(\mathrm{x}_{1}, \mathrm{x}_{2}, \ldots, \mathrm{x}_{\mathrm{n}}\right)$ \{where $\mathrm{x}_{1}, \mathrm{x}_{2}$, up to $\mathrm{x}_{\mathrm{n}}$ are independent variables having distinct errors: $\left.\Delta \mathrm{x}_{1}, \Delta \mathrm{x}_{2}, \ldots, \Delta \mathrm{x}_{\mathrm{n}}\right\}$, the uncertainty analysis

(combined) was carried out for the engine performance parameters using the root mean square method (Panda et al. 2017). The Eq. 1 presented below shows the total uncertainty of a specified parameter. Table 3 represents the total uncertainty of brake power and BSEC calculated as per Eq. 1.

$$
\Delta U=\sqrt{\left\{\left(\frac{\partial U}{\partial x_{1}} \Delta X_{1}\right)^{2}+\left(\frac{\partial U}{\partial x_{2}} \Delta X_{2}\right)^{2}+\ldots+\left(\frac{\partial U}{\partial x_{n}} \Delta X_{n}\right)^{2}\right\}}
$$


Table 3

Total uncertainty (\%) of performance parameters

\begin{tabular}{|c|c|c|c|c|c|}
\hline Parameter & $\begin{array}{l}\text { Measured } \\
\text { variables }\end{array}$ & $\begin{array}{l}\text { Components } \\
\text { involved }\end{array}$ & $\begin{array}{l}\text { Equipment } \\
\text { uncertainty } \\
\text { (\%) [18] }\end{array}$ & Mathematical formulation & $\begin{array}{l}\text { Total } \\
\text { uncertainty } \\
(\%)\end{array}$ \\
\hline $\begin{array}{l}\text { Brake } \\
\text { power }\end{array}$ & $\begin{array}{l}\text { Revolution } \\
\text { per minute, } \\
\text { load }\end{array}$ & $\begin{array}{l}\text { Speed } \\
\text { measuring } \\
\text { unit, } \\
\text { load sensor, } \\
\text { load } \\
\text { indicator }\end{array}$ & $\begin{array}{l}0.1 \\
0.2 \\
1.0\end{array}$ & $\sqrt{(0.1)^{2}+(0.2)^{2}+(1.0)^{2}}$ & 1.02 \\
\hline BSEC & $\begin{array}{l}\text { Fuel } \\
\text { Consumption } \\
\text { (only for } \\
\text { liquid fuel), } \\
\text { brake power }\end{array}$ & $\begin{array}{l}\text { As for brake } \\
\text { power } \\
\text { estimation, } \\
\text { Fuel } \\
\text { calibrating } \\
\text { unit, flow } \\
\text { fuel } \\
\text { transmitter. }\end{array}$ & $\begin{array}{l}1.5 \\
1.02 \\
0.065 .\end{array}$ & $\sqrt{(1.5)^{2}+(1.02)^{2}+(0.065)^{2}}$ & 1.81 \\
\hline
\end{tabular}

\section{Results And Discussion}

The obtained engine experimentation results with KME and KME-DTBP blends in the form of engine performance parameters, viz. BTE, BSEC and EGT along with exhaust emissions, viz. $\mathrm{CO}, \mathrm{HC}, \mathrm{NO}_{\mathrm{x}}$ and smoke opacity were analyzed critically and compared with those for diesel fuel. Again, the comparative analyses of the in-cylinder peak pressure with the selected blends along with diesel has been presented in this section for better understanding of the combustion pattern of these fuels. These comparative analyses carried out at selected engine loading conditions are presented in the following subsections along with valid discussions in order to ascertain the improvement/deterioration in the said performance and exhaust emissions characteristics.

\subsection{In-cylinder Peak Pressure}

The variations of in-cylinder peak pressure for KME, KMED1, KMED2, KMED3, KMED5, and diesel at 85\% load and at rated load with respect to crank movement are presented in Figs. 2 (a) and (b), respectively. It is clearly observed that the highest peak pressure at both $85 \%$ and $100 \%$ loads is achieved with diesel that shows its better combustion pattern compared to the other fuels due to its higher calorific value and lower viscosity. Similarly, the lowest peak pressure is achieved with KME at both the mentioned loads, which signifies its poor combustion pattern compared to the other blends and diesel owing to its lower cetane index, calorific value and higher viscosity. It is also observed that the peak pressure at both considered loads increases with increment in DTBP percentage in the blends. Among all considered biodiesel blends, KMED 5 exhibits highest peak pressure at both conditions. This may be credited to the higher calorific value, higher cetane index and lower viscosity of KMED5 compared to the other blends. The trend of combustion results signifies that use of additive with biodiesel improve the fuel properties, which in turn improve the combustion characteristics of the resulting blend. These results are in agreement with the published literature (Panda et al. 2017; Panda et al. 2018). Further, the 
combustion analysis reveals that KMED5 is the most suitable fuel among all the considered biodiesel blends owing to its better fuel properties.

1. (a) At $85 \%$ load

2. (b) At $100 \%$ load

Figure 2. Variation of in-cylinder peak pressure

\subsection{Brake Thermal Efficiency}

Figure 3 demonstrates the variation of BTE with load. It is detected that BTE increases initially up to $85 \%$ load and then somewhat decreases until full load irrespective of the type of fuel used. This shows better combustion at higher loads, which is the common trend of a $\mathrm{Cl}$ engine. At higher loads, the amount of fuel supplied is more that leads to higher brake power and BTE (Devarajan et al. 2019b). The BTE was found to be highest for diesel at all loads. Among the biodiesel fuels, KMED5 showed highest BTE at all loads. This may be credited to the higher cetane index and calorific value along with lower viscosity of KMED5 that resulted in better atomization, mixing and superior combustion compared to other biodiesel fuels. It is further observed that addition of DTBP with KME resulted in better combustion and higher BTE compared to neat biodiesel. These results are in covenant with published literature (Devarajan et al. 2018). At 85\% load, KMED5 showed the highest BTE among the biodiesel fuels that was a marginal $2.35 \%$ lower than that for diesel. Again, at full load, the BTE with KMED5 was the highest amid all the biodiesels and was lesser by only $2.8 \%$ compared to that with diesel.

Figure 3. Variation of BTE with load

\subsection{Brake Specific Energy Consumption}

The variation of BSEC with load is presented in Fig. 4. It is noticed that BSEC initially decreases up to $85 \%$ load and then marginally increases until full load with all the fuels. Higher BSEC at low loads is owing to incomplete combustion because of lower in-cylinder pressure, low turbulence and poor mixing. On the other hand, higher BSEC at high loads is because of rich mixture formation due to increased fuel supply quantity. BSEC with diesel was found to be lowest at all loads. This may be because of higher calorific value of diesel that leads to better combustion efficiency and lower fuel energy consumption (Devarajan et al. 2018). The BSEC trend also shows that with increase in DTBP percentage in KME, BSEC gradually reduces. This signifies better combustion efficiency with addition of DTBP in KME. The same may be attributed to the increase in cetane index and calorific value as well as reduction in viscosity with addition of DTBP in the blend that leads to improved atomization and superior combustion. These results are well supported by the findings of the published literature (Yilmaz and Atmanli 2017). Among all selected biodiesel fuels, KMED5 showed lowest BSEC at all loads. At $85 \%$ load, BSEC with KMED5 was found to be only $1.09 \%$ higher than that with diesel. Again, the same for KMED5 was found to be $2.34 \%$ higher matched to that with diesel.

Figure 4. Variation of BSEC with load

\subsection{Exhaust Gas Temperature}

The variation in EGT with load is depicted in Fig. 5. EGT is found to be increasing with rise in load irrespective of the fuel used. With increase in load, the in-cylinder pressure and temperature tends to increase those result in higher EGT. Diesel produces lowest EGT at all loads. Biodiesel, being an oxygenated fuel, produces higher 
combustion temperature, which in turn results in higher EGT (Yilmaz and Atmanli 2017; Xue et al. 2011). It is further detected that upsurge in DTBP percentage in KME leads to higher EGT. The probable reason for this is the increase in cetane index and calorific value of KME with increase in DTBP content in the blend. The same results in early start of combustion and a prolonged secondary-phase combustion leading to higher EGT. These findings and their explanations are in agreement with the published literature (Xue et al. 2011). The highest EGT were observed at full load with all the fuels. At this load, the lowest EGT of $447.6^{\circ} \mathrm{C}$ was obtained with diesel and the highest of $508^{\circ} \mathrm{C}$ was obtained for KMED5. Again, EGT for diesel was found to be $7.9 \%, 8.8 \%, 9.7 \%, 10.7 \%$, and $13.5 \%$ lower compared to that with KME, KMED1, KMED2, KMED3, and KMED5 respectively, at full load.

Figure 5. Variation of EGT with load

\subsection{Carbon Monoxide}

Figure 6 depicts the variation in $\mathrm{CO}$ emissions with load. It is detected that the $\mathrm{CO}$ emissions for all the selected fuels are slightly on the higher side at lower engine loads, are lowest at $85 \%$ load and are significantly higher after 85\% load. At lower engine loads, incomplete combustion takes place due to lower in-cylinder temperature and pressure as well as less turbulence. Because of this, the $\mathrm{CO}$ emissions are slightly on the higher side (Gharehghani and Pourrahmani 2019). Further, lowest CO emissions at 85\% load are due to better combustion. On the other hand, sharp increase in $\mathrm{CO}$ emissions observed after $85 \%$ load are mainly because of imperfect combustion owing to formation of rich mixture as a result of higher injection pressures along with the higher incylinder temperature at which the $\mathrm{CO}_{2}$ molecules dissociate to form $\mathrm{CO}$. These results settle with the outcomes in the published literature (Gharehghani and Pourrahmani 2019; Roy et al. 2013). It is further observed that blending of DTBP additive with KME results in reduction of $\mathrm{CO}$ emissions. The $\mathrm{CO}$ emissions tend to decrease with rise in percentage of the additive in KME. This may be credited to the enhancement of calorific value along with cetane index as well as decrease in viscosity of the fuel due to addition of the additive, which is reflected in Table 1. Roy et al. (2016) have verified that addition of cetane improving additive to biodiesel lowers $\mathrm{CO}$ emissions. The highest $\mathrm{CO}$ emissions were obtained for diesel, which is due to the availability of less oxygen, whereas the lowest was obtained with KMED5 blend among all selected fuels. At the best performing load (85\%), the CO emissions with KMED5 was found to be 10.8\%, 16.2\%, 18.9\%, 24.3\% and 29.7\% lower than those with KMED3, KMED2, KMED1, KME and diesel, respectively. Again, KMED5 was found to produce $13.22 \%, 18.18 \%, 33.88 \%, 38.02 \%$, and 43.8\% lower CO emissions compared to KMED3, KMED2, KMED1, KME and diesel, respectively. The lowest CO emissions of $0.037 \%$ and $0.121 \%$ were recorded with KMED 5 at $85 \%$ and $100 \%$ load, respectively.

Figure 6. Variation of $\mathrm{CO}$ emissions with load

\subsection{Unburned Hydrocarbons}

The deviation in $\mathrm{HC}$ emissions with engine load is presented in Fig. 7. The obtained results show that the $\mathrm{HC}$ emissions initially decrease with rise in load up to $85 \%$ load and then increase at a stiff rate until full load irrespective of the type of fuel used. Higher $\mathrm{HC}$ emissions at lower range of loads is due to incomplete combustion that is caused by lower cylinder pressure and temperature, weak turbulence, improper mixing and less availability of oxygen (Roy et al. 2013; Dhar et al. 2012). The lowest HC emissions were observed at $85 \%$ load for all the fuels that shows better combustion at this load. The rapid growth in $\mathrm{HC}$ emissions for all the fuels after $85 \%$ load is attributed to formation of rich fuel-air mixture due to greater injection pressures leading to incomplete combustion (Radhakrishnan et al. 2017). The HC emissions with KME and its blends with DTBP was observed to be lower at all loads matched to diesel. This may be credited to the higher oxygen content in case of 
biodiesel and the higher cetane index of KME and its blends with DTBP that leads to improved combustion compared to diesel (Radhakrishnan et al. 2017; Doğan 2011). Again, the HC emissions in case of KME was observed to reduce with increase in percentage of DTBP. This is due to the mutual effect of decline in viscosity and enhancement in cetane index and calorific value that leads to improved atomization and superior combustion (Atmanli et al. 2014). In addition, increase in percentage of DTBP in KME lowers the ignition delay and enhances mixing of fuel and air. Consequently, the combustion rate is improved, which lowers the HC emissions (Kumar et al. 2016). The above-depicted results are in harmony with the work of Devarajan et al. (2017a). The lowest HC emissions were obtained with KMED5, whereas the same was found to be highest with diesel at all loads. At 85\% load, the HC emissions with KMED5 was observed to be $24.3 \%, 36.2 \%, 42.8 \%, 45.3 \%$, and $70.5 \%$ lower compared to KMED3, KMED2, KMED1, KME, and diesel, respectively. Similarly, 8.65\%, 16.26\%, 22.3\%, 27.1\%, and 58.02\% lower HC emissions were recorded with KMED5 compared to KMED3, KMED2, KMED1, $\mathrm{KME}$, and diesel respectively, at $100 \%$ load. The lowest $\mathrm{HC}$ emissions of $13.23 \mathrm{ppm}$ and 36.78 ppm were recorded with KMED 5 at $85 \%$ and $100 \%$ load, respectively.

Figure 7. Variation of $\mathrm{HC}$ emissions with load

\subsection{Nitrogen Oxides}

Nitrogen oxide is a common term for $\mathrm{NO}$ and $\mathrm{NO}_{2}$ expressed as the formula $\mathrm{NO}_{\mathrm{x}}$. Mainly two types of $\mathrm{NOx}$ formation is believed to occur in the $\mathrm{Cl}$ engine combustion chamber. They are thermal $\mathrm{NO}_{\mathrm{x}}$ (Zeldovich

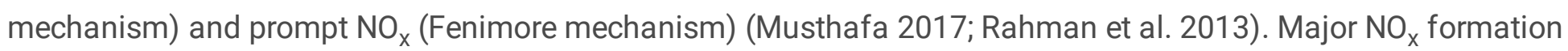
is due to thermal $\mathrm{NO}_{\mathrm{x}}$ that primarily depends on the availability of oxygen, mixture temperature and a longer residence time of high temperature gases (Gharehghani and Pourrahmani 2019; Gharehghani et al. 2017; Özener 2014). The variation of $\mathrm{NO}_{\mathrm{x}}$ emissions for all the selected fuels are depicted in Fig. 8. It is noticed that the $\mathrm{NO}_{\mathrm{x}}$ emissions upsurge with rise in engine load for all the fuels. At higher loads, the in-cylinder temperature is higher due to combustion of larger quantity of fuel. This in turn, increases the residence time of higher temperature leading to higher $\mathrm{NO}_{\mathrm{x}}$ emissions (Devarajan et al. 2019b; Joy et al. 2019). Highest $\mathrm{NO}_{\mathrm{x}}$ emissions were observed at $100 \%$ load for all selected fuels. Again, biodiesels produce more $\mathrm{NO}_{\mathrm{x}}$ emissions compared to diesel (Musthafa 2017; Devarajan et al. 2019a). This is attributed to the higher oxygen content in biodiesels that leads to increased rate of combustion and higher temperature of combustion gases. Thus, the present trend of $\mathrm{NO}_{\mathrm{x}}$ emissions are found to be lowest for diesel among all the fuels at all engine loads. It is further witnessed that the $\mathrm{NO}_{\mathrm{x}}$ emissions slightly increase with increment in DTBP percentage in KME. Addition of DTBP to KME enhances the cetane index and calorific value, whereas it also reduces the viscosity of the blend. This result in a shorter delay period, early start of combustion, increased premixed combustion phase as well as improved atomization and mixing. The collective effect of all these factors leads to longer residence time of high temperature in the combustion chamber, giving rise to higher $\mathrm{NO}_{\mathrm{x}}$ emissions (Enweremadu and Rutto 2010; Pattanaik and Misra 2018; Pattanaik et al. 2017). Thus, KMED5 having highest DTBP percentage, exhibited highest $\mathrm{NO}_{\mathrm{x}}$ emissions among all the fuels at all loads, However, this increment in $\mathrm{NO}_{\mathrm{x}}$ emissions for KMED5 is found to be nominal. The highest $\mathrm{NO}_{\mathrm{x}}$ emissions of 1277.6 ppm and 1366.5 ppm were recorded with KMED5 at $85 \%$ and $100 \%$ load, respectively. On the other hand, diesel exhibited lowest $\mathrm{NO}_{\mathrm{x}}$ emissions of $1165.66 \mathrm{ppm}$ and $1234.6 \mathrm{ppm}$ at $85 \%$ and $100 \%$ load, respectively. At the best performing load of $85 \%$, the $\mathrm{NO}_{\mathrm{x}}$ emissions with KMED5 was observed to be higher by $1.48 \%, 1.72 \%, 3.37 \%, 2.93 \%$, and $8.76 \%$ compared to those with KMED3, KMED2, KMED1, KME, and diesel, 
respectively. Likewise, the same at $100 \%$ load was found to be $0.57 \%, 2.48 \%, 3.1 \%, 3.23 \%$, and $9.65 \%$ higher compared to those with KMED3, KMED2, KMED1, KME, and diesel, respectively.

Figure 8. Variation of $\mathrm{NO}_{\mathrm{x}}$ emissions with load

\subsection{Smoke Opacity}

Diesel smoke is the combination of aerial particulate matter and gases produced during combustion. The smoke is measured in the smoke meter by means of light absorbed through an exhaust gas column of defined specific length. The same is expressed as smoke opacity. The variations of smoke opacity with engine load for diesel, KME, KMED1, KMED2, KMED3, and KMED5 are presented in Fig. 9. It is noticed that the smoke opacity linearly increases with rise in engine load irrespective of the type of fuel used. Further, the same is observed to be increasing significantly at higher loads. At higher loads, the amount of fuel supplied is greater in order to maintain a constant power output. This in turn, results in rich fuel-air mixtures that leads to incomplete combustion (Devarajan et al. 2017b; Mahalingam 2018). Hence, smoke opacity are significantly higher at high engine loads. Diesel exhibited higher smoke opacity at all loads compared to the biodiesel fuels. The same can be attributed to the existence of oxygen in biodiesels that ensures better combustion and less smoke formation compared to diesel. Again, addition of DTBP to KME showed reduction in smoke opacity. It is witnessed that smoke opacity tends to reduce with higher percentage of DTBP in KME. This may be attributed to the reduction in viscosity along with enhancement in cetane index due to increase in additive percentage in biodiesel. Reduction in viscosity improves the atomization process and produces better mixing of fuel with air. In addition, improved cetane index lowers the delay period that leads to early commencement of combustion. The combined effect of the same results in improved combustion in the primary combustion phase that produces lower smoke formation (Pandian 2017). KMED5 showed lowest smoke opacity among all the tested fuels at all loads. The lowest smoke opacity observed at $85 \%$ and $100 \%$ load are $21.45 \%$ and $40.12 \%$, respectively. At $85 \%$ load, the smoke opacity of KMED5 was found to be $14.5 \%, 24.85 \%, 37.3 \%, 41.95 \%$, and $65.82 \%$ lower compared to KMED3, KMED2, KMED1, KME, and diesel, respectively. Similarly, the same for KMED 5 at $100 \%$ load was found to be lower by $6.58 \%, 10.24 \%$, $14.33 \%, 16.0 \%$, and $37.68 \%$ compared to KMED3, KMED2, KMED1, KME, and diesel, respectively.

Figure 9. Variation of smoke opacity with load

\section{Economic Analysis}

The economic factors affecting biodiesel production could be the cost of raw material, capital and chemicals used and capacity of plant and technology used. Out of these, $80 \%$ is the raw material cost and the rest includes cost of chemicals (catalyst and methanol) as well as labour (Panda et al. 2018). In this work, the estimated cost of production (US\$) of KME from neat karanja oil was found to be $0.7 /$ lit that is inclusive of raw material cost, cost of chemicals and labour expenses. These costs can be lessened if there are some ways to reuse the byproduct glycerol. In addition, if the feedstock is selected appropriately, the overall cost might reduce. These days, as the non-food crops are favourable sources for biofuels production, this can be seen as an opportunity to upsurge the production of biodiesel. Other socio-economic factors, such as regional development, sustainability, agriculture with social structure, supply security etc. may add to the advantage of biodiesel over diesel and other petroleum products. Further, the local economy may be significantly promoted through the use of developed biofuels for power production. 


\section{Conclusions}

The effect of DTBP addition to KME on the engine performance and exhaust emissions characteristics was studied along with a comparative analysis with diesel oil. The key findings evolved out of the present work are summarized below.

- The fuel properties of KME significantly improved with addition of DTBP. The cold flow properties, viz. viscosity, cloud point and pour point reduce with increment in DTBP percentage in the blend. Similarly, DTBP addition with KME enhanced the calorific value and cetane index of the blend.

- Improved combustion is achieved with the use of DTBP additive in KME. Further, combustion gets better with rise in DTBP content in the biodiesel blend.

- KME and DTBP blends produce higher BTE than neat karanja biodiesel. However, BTE with KME-DTBP blends are lower compared to diesel under all working conditions.

- Doping DTBP to KME reduces BSEC owing to improved combustion inside the engine cylinder. However, KME-DTBP blends show higher BSEC compared to diesel because of their higher viscosity and low calorific value.

- EGT increases with increase in DTBP content in KME-DTBP blends owing to greater availability of oxygen in the blends. Diesel shows lowest EGT at all loads compared to the biodiesel blends.

- $\mathrm{CO}$ emissions are highest for diesel especially at higher loads owing to lower oxygen availability. Further, the same tend to decline with rise in DTBP percentage in the KME-DTBP blends as a result of improved combustion.

- HC emissions are highest in case of diesel under all working conditions due to lower availability of oxygen. Further, addition of DTBP lowers the HC emissions of KME owing to better combustion as a result of reduction in viscosity along with enhancement in calorific value and cetane index.

- $\mathrm{NO}_{\mathrm{x}}$ emissions are greater with all the biodiesel blends matched to diesel at all loads due to their higher oxygen content. Again, the $\mathrm{NO}_{x}$ emissions tend to increase with rise in additive percentage in KME-DTBP blends as a consequence of rise in oxygen content, cetane index and calorific value of the blends that gives rise to a longer residence time of high temperature.

- Smoke opacity is highest for diesel at all working loads, whereas the same reduces with rise in DTBP content in the KME-DTBP blends. This signifies better combustion with increment in DTBP percentage in the blends.

It may be concluded that addition of DTBP enhances biodiesel performance and lowers the exhaust emissions in a diesel engine. The present work establishes $100 \%$ replacement of diesel oil in a diesel engine with KME-DTBP blends, while maintaining satisfactory engine performance along with lower exhaust emissions. However, this work unveils further scope of research to lower the $\mathrm{NO}_{x}$ emissions with $\mathrm{KME}$-DTBP blends, which are marginally higher, compared to diesel.

\section{References}

1. Agarwal AK (2007) Biofuels (alcohols and biodiesel) applications as fuels for internal combustion engines. Progress in Energy and Combustion Science 33:233-271. https://doi.org/10.1016/j.pecs.2006.08.003 
2. Atmanli A, lleri E, Yüksel B (2014) Experimental investigation of engine performance and exhaust emissions of a diesel engine fueled with diesel-n-butanol-vegetable oil blends. Energy Conversion and Management 81:312-321. https://doi.org/10.1016/j.enconman.2014.02.049

3. Channappagoudra M, Ramesh K, Manavendra G (2018) Bio-ethanol additive effect on direct injection diesel engine performance, emission and combustion characteristics-an experimental examination. International Journal of Ambient Energy 2018:1-10. https://doi.org/10.1080/01430750.2018.1517665

4. Demirbas A (2007) Importance of biodiesel as transportation fuel. Energy Policy 35:4661-4670. https://doi.org/10.1016/j.enpol.2007.04.003

5. Demirbaş A (2003) Chemical and fuel properties of seventeen vegetable oils. Energy Sources 25:721-728. https://doi.org/10.1080/00908310390212426

6. Devarajan Y, Choubey G, Mehar K (2019a) Ignition analysis on neat alcohols and biodiesel blends propelled research compression ignition engine. Energy Sources, Part A: Recovery, Utilization, and Environmental Effects 2019:1-12. https://doi.org/10.1080/15567036.2019.1618998

7. Devarajan Y, Munuswamy DB, Mahalingam A, Nagappan B (2017a) Performance, combustion, and emission analysis of neat palm oil biodiesel and higher alcohol blends in a diesel engine. Energy \& Fuels 31:1379613801. https://doi.org/10.1021/acs.energyfuels.7b02939

8. Devarajan Y, Munuswamy DB, Nagappan B, Pandian AK (2018) Performance, combustion and emission analysis of mustard oil biodiesel and octanol blends in diesel engine. Heat and Mass Transfer 54:18031811. https://doi.org/10.1007/s00231-018-2274-x

9. Devarajan Y, Munuswamy DB, Nagappan B, Subbiah G (2019b) Experimental assessment of performance and exhaust emission characteristics of a diesel engine fuelled with Punnai biodiesel/butanol fuel blends. Petroleum Science 16:1471-1478. https://doi.org/10.1007/s12182-019-00361-9

10. Devarajan Y, Nagappan BK, Munuswamy DB (2017b) Performance and emissions analysis on diesel engine fuelled with cashew nut shell biodiesel and pentanol blends. Korean Journal of Chemical Engineering 34:1021-1026. https://doi.org/10.1007/s11814-016-0364-3

11. Dhar A, Kevin R, Agarwal AK (2012) Production of biodiesel from high-FFA neem oil and its performance, emission and combustion characterization in a single cylinder DICl engine. Fuel Processing Technology 97:118-129. https://doi.org/10.1016/j.fuproc.2012.01.012

12. Doğan $O$ (2011) The influence of $n$-butanol/diesel fuel blends utilization on a small diesel engine performance and emissions. Fuel 90:2467-2472. https://doi.org/10.1016/j.fuel.2011.02.033

13. Enweremadu CC, Rutto HL (2010) Combustion, emission and engine performance characteristics of used cooking oil biodiesel-A review. Renewable and Sustainable Energy Reviews 14:2863-2873. https://doi.org/10.1016/j.rser.2010.07.036

14. Gharehghani A, Asiaei S, Khalife E, Najafi B, Tabatabaei M (2019) Simultaneous reduction of $\mathrm{CO}$ and $\mathrm{NO}_{\mathrm{x}}$ emissions as well as fuel consumption by using water and nano particles in Diesel-Biodiesel blend. Journal of Cleaner Production 210:1164-1170. https://doi.org/10.1016/j.jclepro.2018.10.338

15. Gharehghani A, Mirsalim M, Hosseini R (2017) Effects of waste fish oil biodiesel on diesel engine combustion characteristics and emission. Renewable Energy 101:930-936. https://doi.org/10.1016/j.renene.2016.09.045

16. Joy N, Yuvarajan D, Beemkumar N (2019) Performance evaluation and emission characteristics of biodieselignition enhancer blends propelled in a research diesel engine. International Journal of Green Energy 16:277- 
283. https://doi.org/10.1080/15435075.2018.1561455

17. Kumar BR, Muthukkumar T, Krishnamoorthy V, Saravanan S (2016) A comparative evaluation and optimization of performance and emission characteristics of a DI diesel engine fueled with npropanol/diesel, n-butanol/diesel and n-pentanol/diesel blends using response surface methodology. RSC Advances 6:61869-61890. https://doi.org/10.1039/C6RA11643D

18. Lawan I, Zhou W, Idris AL, Jiang Y, Zhang M, Wang L, Yuan Z (2020) Synthesis, properties and effects of a multi-functional biodiesel fuel additive. Fuel Processing Technology 198:106228. https://doi.org/10.1016/j.fuproc.2019.106228

19. Mahalingam A, Munuswamy DB, Devarajan Y, Radhakrishnan S (2018) Investigation on the emission reduction technique in acetone-biodiesel aspirated diesel engine. Journal of Oil Palm Research 30:345-349. https://doi.org/10.21894/jopr.2018.0020

20. Misra RD, Murthy MS (2011) Jatropa-the future fuel of India. Renewable and Sustainable Energy Reviews 15:1350-1359. https://doi.org/10.1016/j.rser.2010.10.011

21. Mohanty C, Jaiswal A, Meda VS, Behera P, Murugan S (2011) An experimental investigation on the combustion, performance and emissions of a diesel engine using vegetable oil-diesel fuel blends. SAE Technical Paper No. 2011-01-1187. https://doi.org/10.4271/2011-01-1187

22. Musthafa MM (2017) Development of performance and emission characteristics on coated diesel engine fuelled by biodiesel with cetane number enhancing additive. Energy 134:234-239. https://doi.org/10.1016/j.energy.2017.06.012

23. Nabi MN, Rahman MM, Akhter MS (2009) Biodiesel from cotton seed oil and its effect on engine performance and exhaust emissions. Applied Thermal Engineering 29:2265-2270. https://doi.org/10.1016/j.applthermaleng.2008.11.009

24. Nayak SK, Pattanaik BP (2014) Experimental investigation on performance and emission characteristics of a diesel engine fuelled with mahua biodiesel using additive. Energy Procedia 54:569-579. https://doi.org/ 10.1016/j.egypro.2014.07.298

25. Ozener O, Yuksek L, Ergenc AT, Ozkan M (2014) Effects of soybean biodiesel on a DI diesel engine performance, emission and combustion characteristics. Fuel 115:875-883.

https://doi.org/10.1016/j.fuel.2012.10.081

26. Palash SM, Kalam MA, Masjuki HH, Masum BM, Fattah IR, Mofijur M (2013) Impacts of biodiesel combustion on $\mathrm{NO}_{x}$ emissions and their reduction approaches. Renewable and Sustainable Energy Reviews 23:473-490. https://doi.org/10.1016/j.rser.2013.03.003

27. Panda JK, Sastry GR, Rai RN (2018) Experimental analysis of performance and emission on DI diesel engine fueled with diesel-palm kernel methyl ester-triacetin blends: a Taguchi fuzzy-based optimization. Environmental Science and Pollution Research 25:22035-22051. https://doi.org/10.1007/s11356-018-22283

28. Panda JK, Sastry GR, Rai RN (2017) A Taguchi-fuzzy-based multi-objective optimization of a direct injection diesel engine fueled with different blends of Leucas zeylanica methyl ester and 2-ethylhexyl nitrate diesel additive with diesel. Journal of Energy Resources Technology 139:1-12. https://doi.org/10.1115/1.4036323

29. Pandian AK, Munuswamy DB, Radhakrishana S, Ramakrishnan RBB, Nagappan B, Devarajan Y (2017) Influence of an oxygenated additive on emission of an engine fueled with neat biodiesel. Petroleum Science 14:791-797. https://doi.org/10.1007/s12182-017-0186-x

Page 13/19 
30. Pattanaik BP, Jena J, Misra RD (2017) The effect of oxygen content in soapnut biodiesel-diesel blends on performance of a diesel engine. International Journal of Automotive and Mechanical Engineering 14:45744588. https://doi.org/10.15282/ijame.14.3.2017.14.0361

31. Pattanaik BP, Misra RD (2018) Experimental studies on production of deoxygenated vegetable oils and their performance evaluation in a compression ignition engine. Biomass Conversion and Biorefinery 8:899-908. https://doi.org/10.1007/s13399-018-0328-4

32. Pattanaik BP, Misra RD (2017) Effect of reaction pathway and operating parameters on the deoxygenation of vegetable oils to produce diesel range hydrocarbon fuels: A review. Renewable and Sustainable Energy Reviews 73:545-557. https://doi.org/10.1016/j.rser.2017.01.018

33. Radhakrishnan S, Devarajan Y, Mahalingam A, Nagappan B (2017) Emissions analysis on diesel engine fueled with palm oil biodiesel and pentanol blends. Journal of Oil Palm Research 29:380-386. https://doi.org/10.21894/jopr.2017.2903.11

34. Ramadhas AS, Jayaraj S, Muraleedharan C (2004) Use of vegetable oils as IC engine fuels-a review. Renewable Energy 29:727-742. https://doi.org/10.1016/j.renene.2003.09.008

35. Roy MM, Alawi M, Wang W (2013) Effects of canola biodiesel on a DI diesel engine performance and emissions. International Journal of Mechatronics Engineering 13:46-53. https:// dx.doi.org/10.1016/j.fuel.2012.10.081

36. Roy MM, Calder J, Wang W, Mangad A, Diniz FCM (2016) Emission analysis of a modern Tier 4 DI diesel engine fueled by biodiesel-diesel blends with a cold flow improver (Wintron Synergy) at multiple idling conditions. Applied Energy 179:45-54. https://doi.org/10.1016/j.apenergy.2016.06.129

37. Roy MM, Wang W, Alawi M (2014) Performance and emissions of a diesel engine fueled by biodiesel-diesel, biodiesel-diesel-additive and kerosene-biodiesel blends. Energy Conversion and Management 84:164-173. https://doi.org/10.1016/j.enconman.2014.04.033

38. Smith PC, Ngothai Y, Nguyen QD, O'Neill BK (2010) Improving the low-temperature properties of biodiesel: Methods and consequences. Renewable Energy 35:1145-1151.

https://doi.org/10.1016/j.renene.2009.12.007

39. Tan PQ, Hu ZY, Lou DM, Li ZJ (2012) Exhaust emissions from a light-duty diesel engine with Jatropha biodiesel fuel. Energy 39:356-362. https://doi.org/10.1016/j.energy.2012.01.002

40. Xue J, Grift TE, Hansen AC (2011) Effect of biodiesel on engine performances and emissions. Renewable and Sustainable Energy Reviews 15:1098-1116. https://doi.org/10.1016/j.rser.2010.11.016

41. Yang PM, Lin KC, Lin YC, Jhang SR, Chen SC (2016) Emission evaluation of a diesel engine generator operating with a proportion of isobutanol as a fuel additive in biodiesel blends. Applied Thermal Engineering 100:628-635. https://doi.org/10.1016/j.applthermaleng.2016.01.118

42. Yasin MM, Yusaf T, Mamat R, Yusop AF (2014) Characterization of a diesel engine operating with a small proportion of methanol as a fuel additive in biodiesel blend. Applied Energy 114:865-873. https://doi.org/10.1016/j.apenergy.2013.06.012

43. Yilmaz N, Atmanli A (2017) Experimental assessment of a diesel engine fueled with diesel-biodiesel-1pentanol blends. Fuel 191:190-197. https://doi.org/10.1016/j.fuel.2016.11.065

\section{Figures}




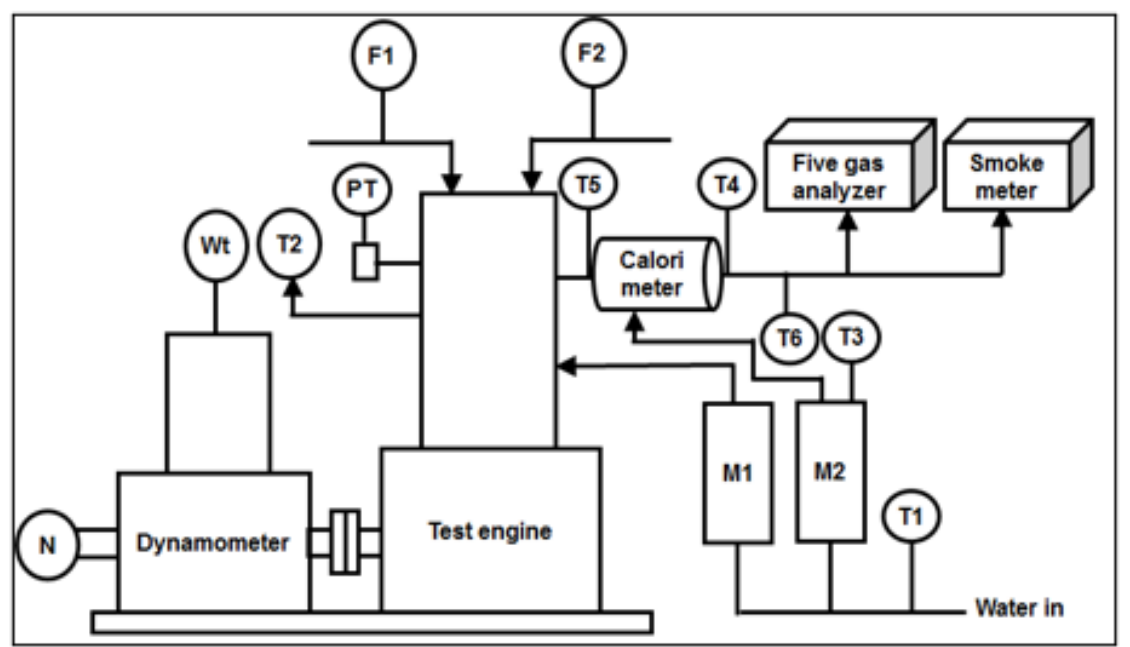

F1: Fuel injection pressure sensor

$\mathrm{T} 1$ : Cooling water inlet temperature to engine and calorimeter

T3: Cooling water inlet temperature to calorimeter

T5: Exhaust gas inlet temp to calorimeter

PT: Piezo sensor

M1: Water flow meter for engine
F2: Air flow meter

$\mathrm{T} 2$ : Cooling water outlet temperature from engine

T4: Cooling water outlet temperature from calorimeter

T6: Exhaust gas outlet temp from calorimeter

$\mathrm{N}$ : rpm pick up and TDC encoder

M2: Water flow meter for Calorimeter

Fig. 1. Schematic diagram of the experimental engine setup

\section{Figure 1}

Schematic diagram of the experimental engine setup

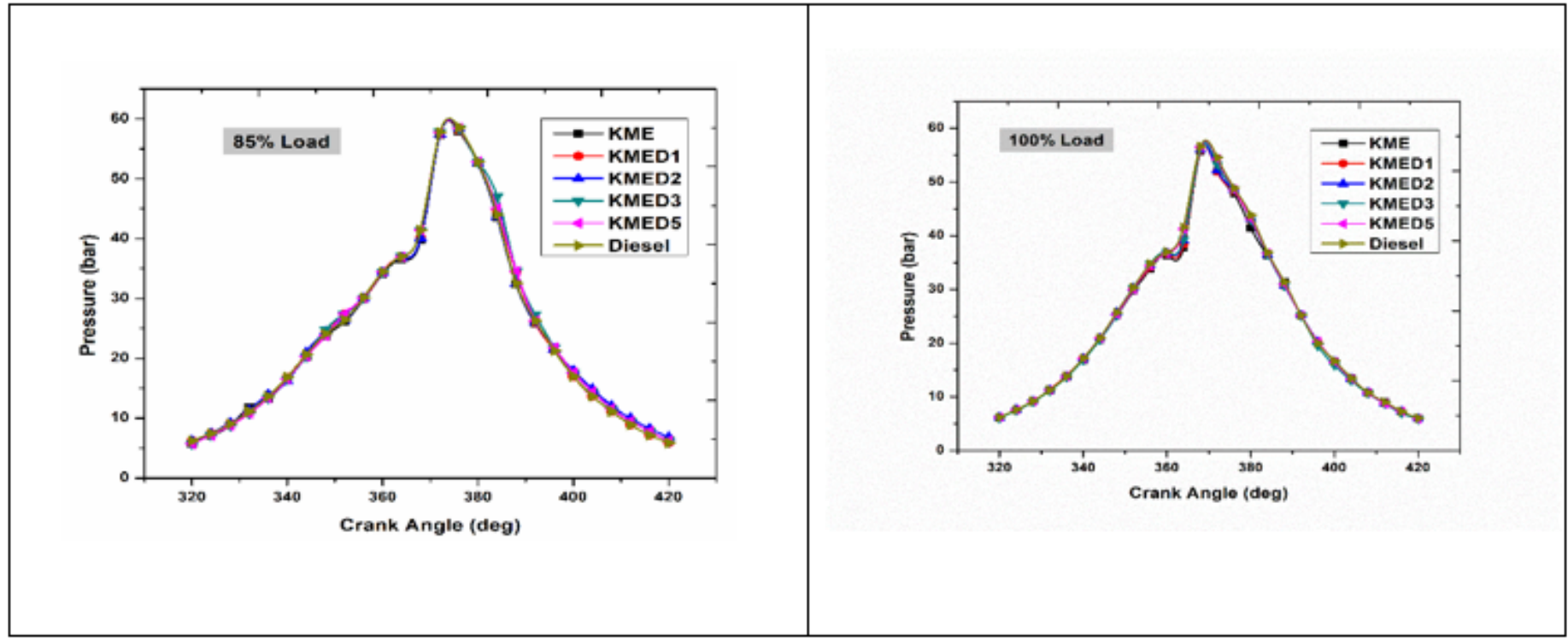

Fig. 2. Variation of in-cylinder peak pressure

Figure 2 




Figure 3

Variation of BTE with load

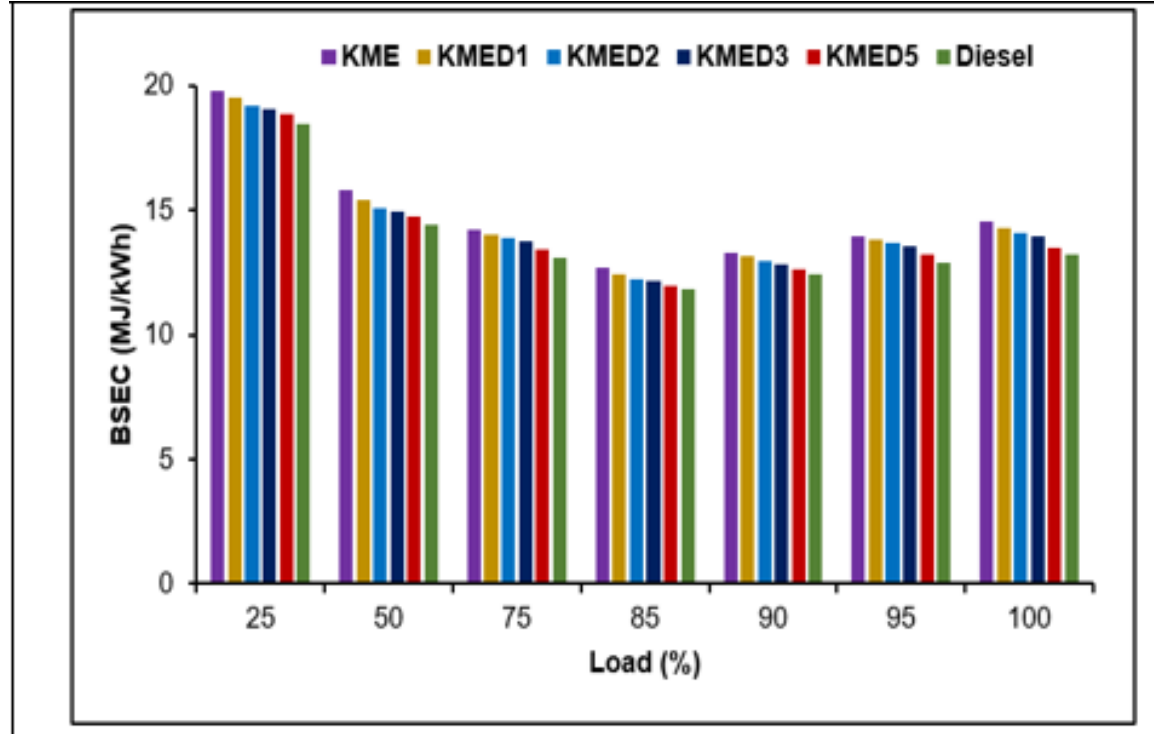

Fig 4. Variation of BSEC with load

Figure 4

Variation of BSEC with load 


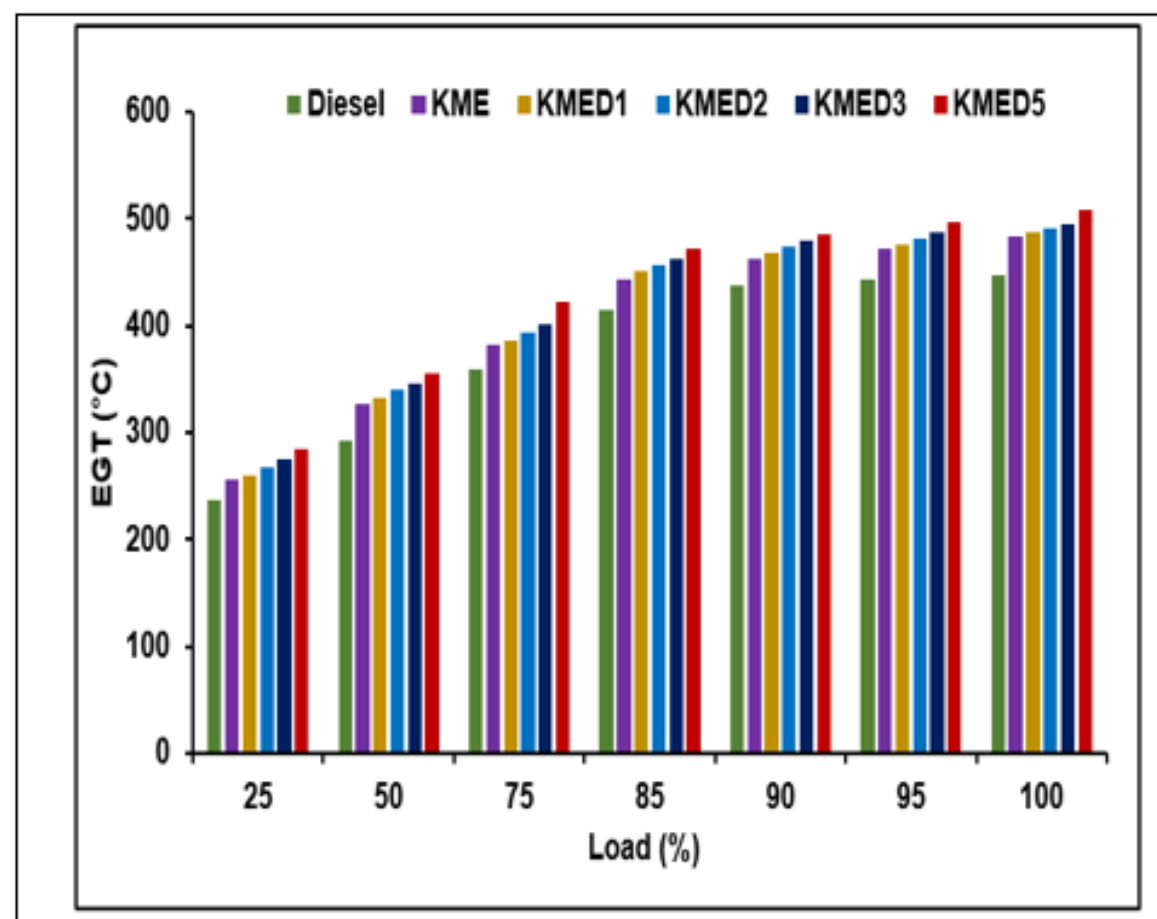

Fig. 5. Variation of EGT with load

Figure 5

Variation of EGT with load



Figure 6

Variation of $\mathrm{CO}$ emissions with load 


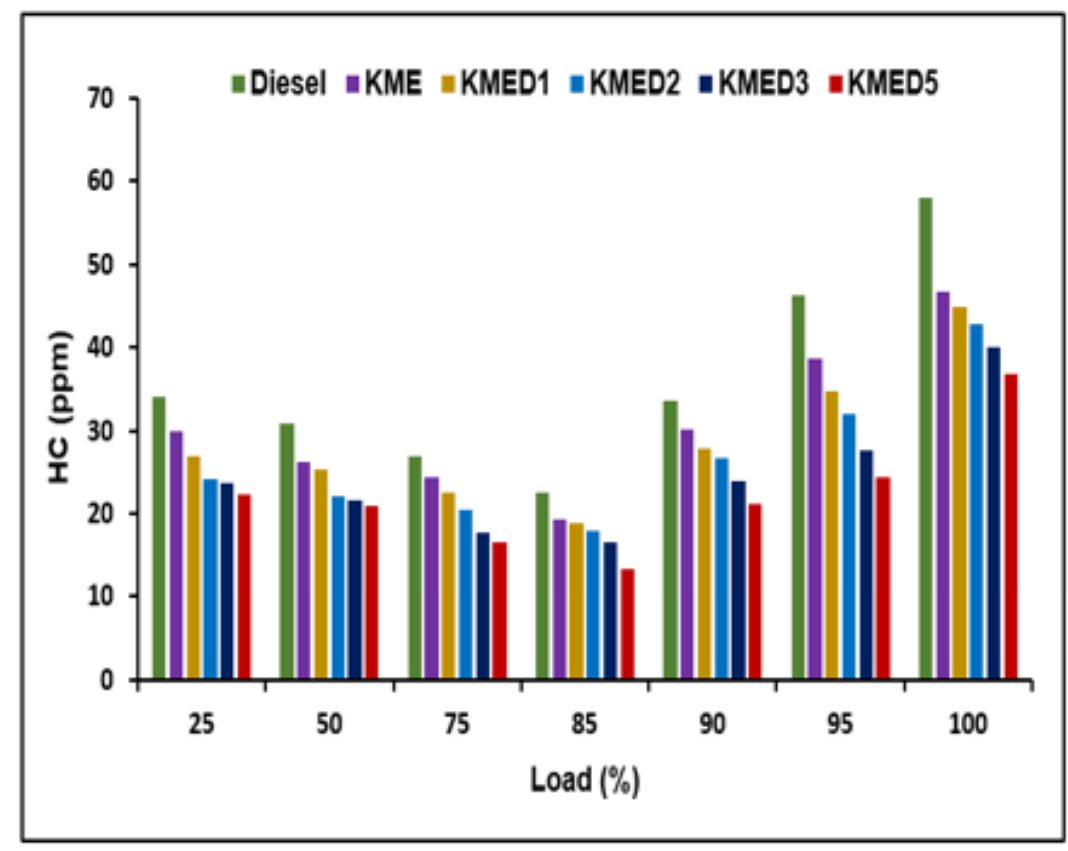

Fig. 7. Variation of $\mathrm{HC}$ emissions with load

Figure 7

Variation of $\mathrm{HC}$ emissions with load

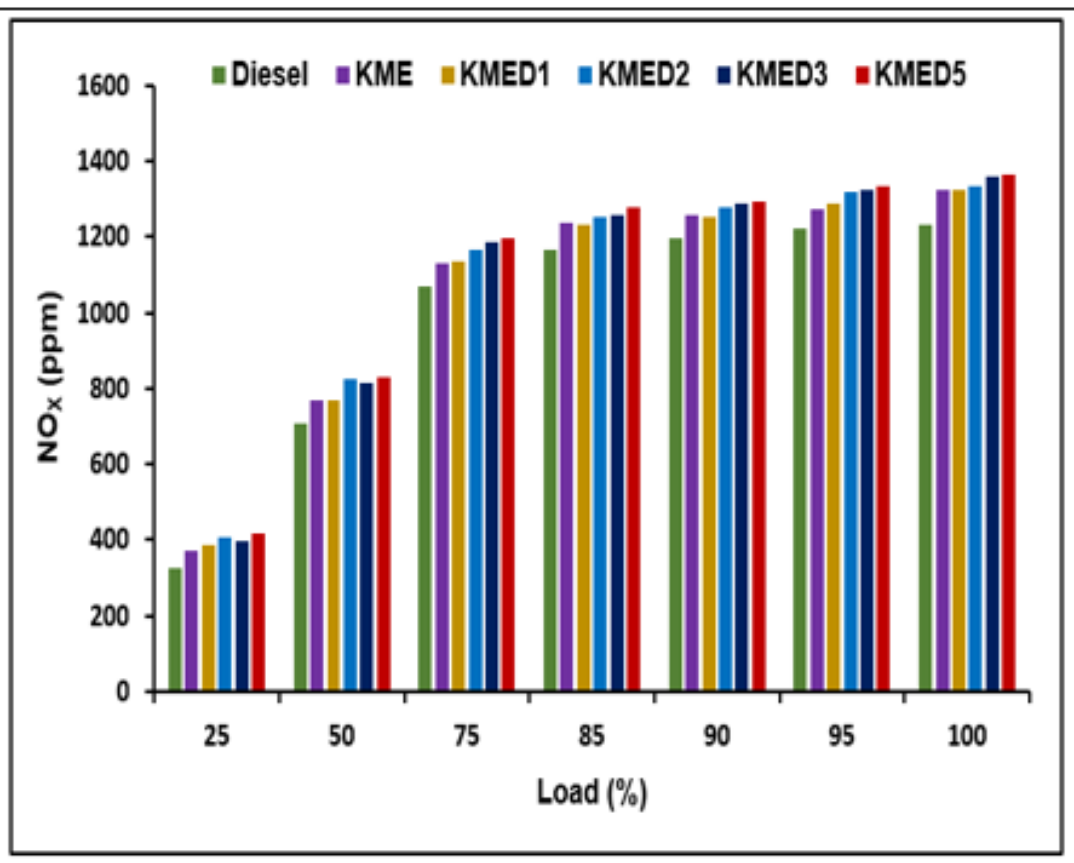

Fig. 8. Variation of $\mathrm{NO}_{\mathrm{x}}$ emissions with load

Figure 8

Variation of NOx emissions with load 




Fig. 9. Variation of smoke opacity with load

Figure 9

Variation of smoke opacity with load 